\title{
Tamamlayıcı Tıp Uygulamaları: Refleksoloji
}

\author{
Hümeyra YÜKSEL \\ Nevşehir Devlet Hastanesi, Yoğun Bakım Ünitesi, Nevşehir, Türkiye \\ Sorumlu Yazar / Corresponding Author: Hümeyra YÜKSEL, e-posta: humeyragecici@gmail.com
}

\section{ÖZET}

Farmokolojik tedavilerin hastaların ağrılarını azaltmasını kontrol edememesinden dolayı tamamlayıcı ve alternatif tıp yöntemleri tekrardan önem kazanmaya başlamıştır. Ağrı azaltılmasında, anksiyete, stres düzeyleri üzerinde refleksoloji kullanımı dünyada ve ülkemizde gün geçtikçe yaygınlaşmaya başlamıştır. Refleksoloji, insanların ayaklarında belirli noktalara bası uygulayarak ağrı, acı, stres, anksiyete ve vücutta bulunan organlarda olan ağrıları dindirilmesine yardımcı olmaktadır. Refleksoloji geçmiş yüzyllardan bu yana kullanılmaktadır. Modern topluma refleksolojiyi tekrardan gündeme getirilmiştir. Refleksoloji birçok meslek grupları tarafından kullanılmaktadır. Hemşireler de ise gün geçtikçe kullanımı artması beklenmektedir. Bu derlemenin amacı tamamlayıcı tıp uygulamalarından biri olan refleksolojinin tanımı kullanım alanlarını ve hemşirelerinde kullanımını artırmak ve literatüre katkı sağlaması amacıyla yazılmıştır.

Anahtar kelimeler: Ağrı, Anksiyete, Hemşire, Refleksoloji, Stres

\section{Complementary Medicine Applications: Reflexology}

\begin{abstract}
Complementary and alternative medicine methods have started to gain importance again due to the inability of pharmacological treatments to control patients' pain reduction. The use of reflexology in reducing pain, anxiety and stress levels has started to become widespread in the world and in our country. Reflexology helps people relieve pain, pain, stress, anxiety and pain in organs in the body by applying pressure to certain points on their feet. Reflexology has been used since past centuries. Reflexology has been brought to the agenda again in modern society. Reflexology is used by many professional groups. It is expected that the use of nurses will increase day by day. The aim of this review is to define reflexology, which is one of the complementary medicine applications, to increase its use in nurses and to contribute to the literature.
\end{abstract}

Key words: Anxiety, Nurse, Pain, Reflexology, Stress

\section{Refleksoloji}

Modern çağda belirgin artış gösteren tedavi yöntemlerinden biri tamamlayıcı ve alternatif tıp (TAT) uygulamalarıdır. Dünya Sağlık Örgütü TAT uygulamalarını bilimsel tıp dışındaki uygulamalar şeklinde tanımlar. Tamamlayıcı tıp uygulamalarını ise bilimsel tedavilere yardımcı olan tedavi uygulamaları şeklinde ifade eder (Lafçı \& Kara Kaşıkçı, 2014).

Refleksoloji kulak, ayak ve ellerdeki refleks noktalarının organlara ait sinir uçlarına basınç uygulanarak yapılan, masaj yoluyla vücuttaki kan 
Journal of Integrative and Anatolian Medicine

Bütünleyici ve Anadolu Tıbbı Dergisi
Cilt/ Volume: 2 Sayı / Issue: 3 Yl1/Year: 2021
Yaynncı / Publisher Sağllk Bilimleri Üniversitesi University of Health Sciences dolaşımını iyileştirmeyi amaçlayan, sağlığın sırrının kan dolaşımında olduğunu kabul eden bir yardımcı tedavi yöntemidir (Dinler, 2015).

Uluslararas1 Refleksoloji Enstitüsünce "tüm salg1 bezleri, organlar ve vücut bölümleri ile ilişkili olan ellerde, ayaklarda ve kulaklardaki refleks noktalarına elle uygulanan, vücut fonksiyonlarının normalleşmesine yardım eden bir teknik" şeklinde tanımlanmıştır. Refleksoloji uygulamalarında; ayak bölgesi, diğer bölgelere oranla daha yaygin tercih edilmektedir (Yildız \& Öztürk, 2014). Refleksoloji tekniğinin amac1, vücudun kendini iyileştirme potansiyelini aktifleştirerek vücudu canlandırmaktır (Metin\& Özdemir, 2016).

\section{Refleksoloji Tarihçesi}

Refleksoloji gibi yöntemlerin 500 y1l öncesinde Hindistan ve Çin'de vücudun belli noktalarına bastırılarak uygulandığ edilmektedir. Ayrıca milattan önce 3000 yıllarında Mısır'da refleksolojiye ait dokümanlar bulunmaktadır. Ayaklardaki noktalara basincin beden ve ruhsal dengedeki önemini Amerikan yerlileri de çok önce keşfetmişlerdir. Modern refleksoloji tarihinde ise karşımıza Amerika'da William H. Fitzgerald çıkmaktadır. Dr. Fitzgerald parmak noktalarına basınç uygulandığında omuzlar, çene, kulaklar, kollar ve burunda anestetik etki yaratıldığını bulmuş ve bölge terapisini ortaya atmıştır. Buradan yola çıkarak vücudu 10 eşit bölgeye ayırmış ve "her bölgede yer alan organlar enerji akımını paylaşarak birbirini etkiler" demiştir. Sonrasında Dr. Riley, bu yöntemi geliştirerek bu 10 hayali bölgeye yatay bölgeler eklemiş ve ayak tabanında organların yansıdığı bazı noktaları şekillendirmiştir (Gözüyeşil, 2015).

Organların ayak tabanındaki noktaları aynı vücudumuzdaki gibidir; iki ayak yan yana geldiğinde Şekil 1'de görüldüğü gibi insan vücudu görüntüsü oluşur. Bu harita refleksoloji uygulaması için yol göstericidir. Böylece organların el ve ayaktaki yansıma noktalarına bası uygulayarak tüm vücutta tedaviye yardımc1 olmak mümkün olmaktadır (Çakıroğlu, 2013).

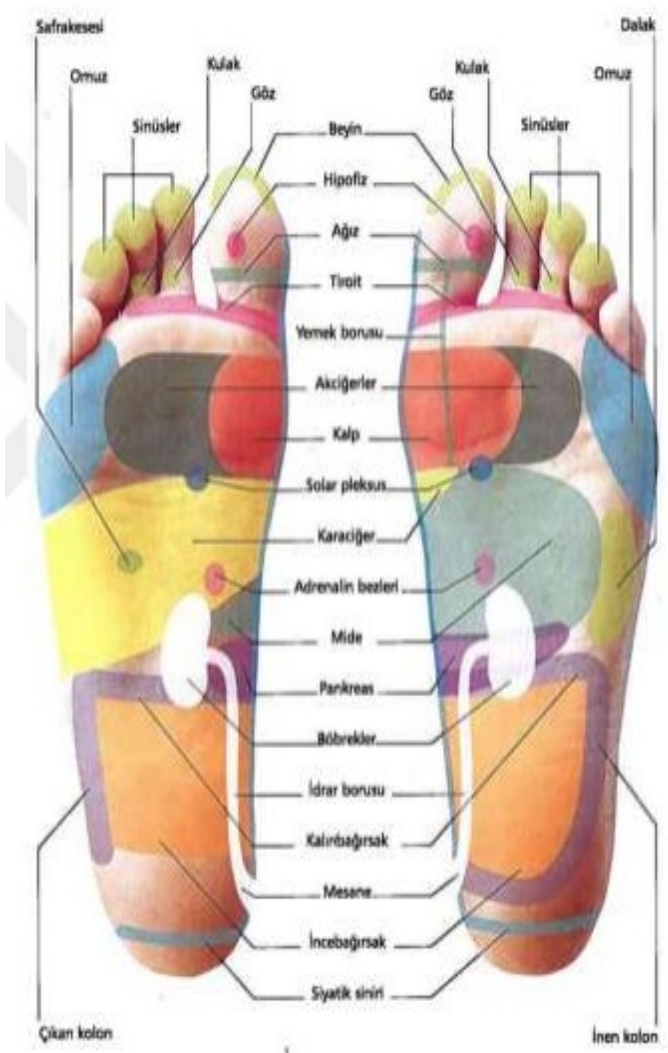

Şekil 1: Ayaklardaki refleks noktaları (Horasanlı ve ark., 2008) 
Journal of Integrative and Anatolian Medicine

Bütünleyici ve Anadolu Tibbı Dergisi
Cilt/ Volume: 2 Sayı / Issue: 3

Yil/Year: 2021
Yayınc1 / Publisher Sağllk Bilimleri Üniversitesi University of Health Sciences

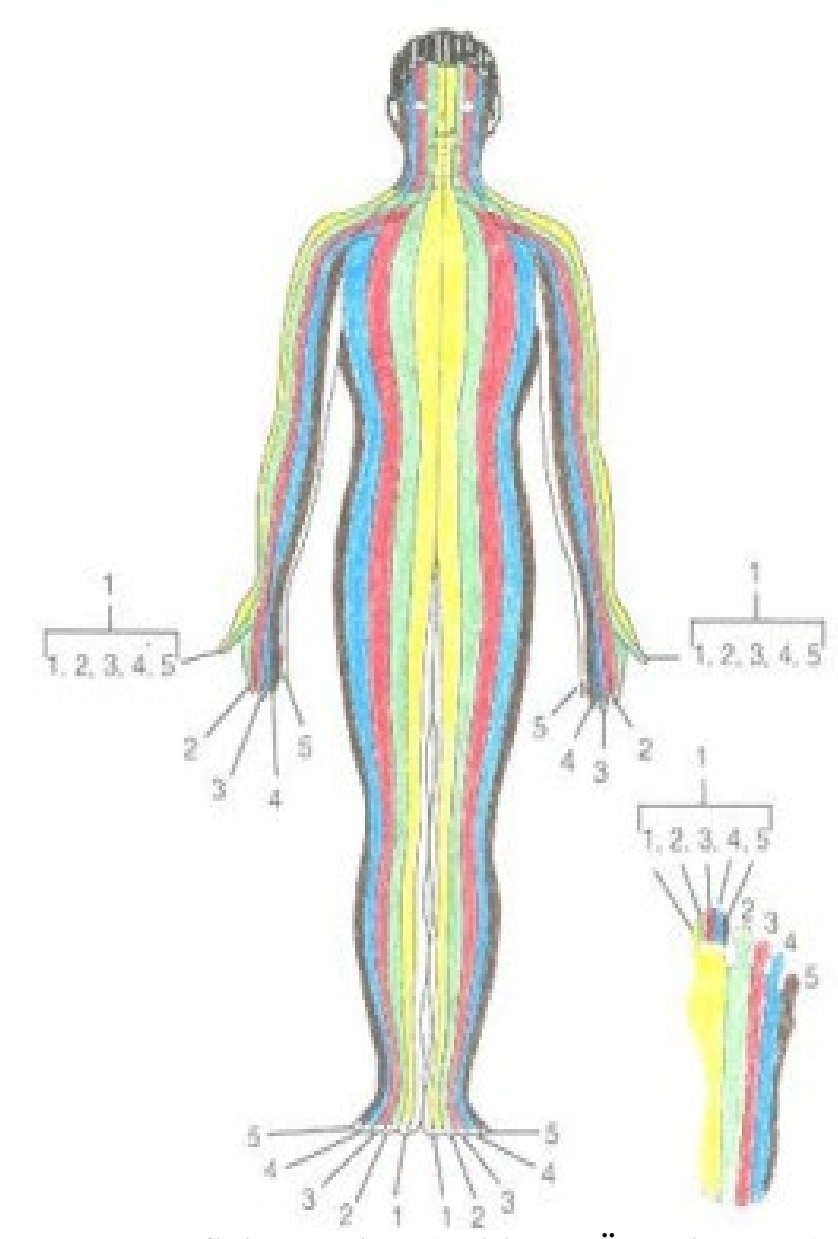

Şekil 2: Refleks Zonları (Yıldız \& Öztürk, 2014).

Refleksoloji (çoğu zaman zon terapi ile aynı anlamda kullanılır) uygulamalarında, vücudun belirli bölgelerinin ayaktaki yansımaları üzerine özel tekniklerle baskı uygulanır. Geleneksel Çin Tıbbı teorilerine göre vücudumuzda longitudinal olarak yol alan ve enerjinin arttı̆̆ 1 kanallar (hayali çizgiler) "zon" olarak adlandırılır (Şekil 2). Ayaktaki yansiyan noktalar, bu zonlar üzerindeki organlar ile bağlantılıdır. $\mathrm{Bu}$ zonlardaki enerji akışında yaşanacak bir durgunluk (stagnation) veya tıkanıklık o zon üzerindeki organların fonksiyonunu etkiler. Ayak zon terapi ile uygun enerji akışını yeniden sağlamayı amaçlarız (Yıldız \& Öztürk, 2014).

\section{Refleksoloji Mekanizması ve Uygulaması}

Refleksoloji mekanizmasi; enerji, laktik asit, propriyoseptif sinir reseptörünü algılama, sinir uyar1/ otonomik-somatik birleşme ve sempatik- parasempatik teorisi olmak üzere genelde beş teori ile açıklanmaktadır:

Enerji teorisine göre; refleksoloji tıkalı kanallarda var olan enerjiyi tekrardan vücuda yayan bir uygulamadır ki bunu da vücuttaki elektromanyetik alanlar arasındaki iletişimi sağlayarak gerçekleştirir (Çevik, 2013, Stephenson ve ark., 2000).

Laktik asit teorisi; ayaklarda laktik asidin mikro kristaller şeklinde depolandığını, refleksoloji ile depolanan bu kristallerin çözünerek enerjinin rahatça akışının sağladığını açıklar. Metabolizmadaki atık ürünlerin özellikle laktik asidin atılımını sağlar. $\mathrm{Bu}$ işleme toksinlerden kurtulma da denir (Çevik, 2013, Stephenson ve ark., 2000).

Propriyoseptif sinir reseptörlerini algılama teorisi; teori ayaklar, kulaklar ve ellerdeki refleks noktalarının organlara etki yaptığını ve bu 
Journal of Integrative and Anatolian Medicine

Bütünleyici ve Anadolu Tıbbı Dergisi
Cilt/Volume: 2 Sayı / Issue: 3 Yll/Year: 2021
Yayncs / Publisher

Sağllk Bilimleri Üniversitesi University of Health Sciences organların ayaktaki refleks bölgeleriyle bağlantılı olduğunu ileri sürer. Refleks bölgelerindeki sinir noktaları belirli refleksoloji teknikleriyle uyarılarak elektrokimyasal mesajlar ortaya çıkarılır. Bu mesajlar sinir hücreleri yardımı ile ilgili organlara iletilir. Böylece vücuttaki gerginlik ve stres rahatlatılarak gevşeme sağlanır. Gevşeme sonucunda otonom yanıt oluşarak endokrin, immün ve nöropeptit sistem etkilenir (Çevik, 2013, Stephenson ve ark., 2000).

Sinir uyarı veya otonomik-somatik birleşme teorisine göre; deride mevcut olan birçok sinir reseptörlerinin hepsinin farklı fizyolojik ve anatomik özellikleri vardır. Teori, refleksoloji uygulaması ile sinir reseptörlere hücrelerdeki plazma zarlarındaki iyonik kanallardan basınç uygulandığını ve bu iletinin beyne ulaştırılması için olumlu yönde bölgesel bir hareket sağladığını savunur (Çevik, 2013, Stephenson ve ark., 2000).

Sempatik-parasempatik teorisi ise son yıllarda karşımıza çıkan bir teoridir. Bu teoriye göre, bireyi rahatlatmak ve sakinleştirmek adına parasempatik sinir sistemini etkilemek için sol el ya da ayak, organizmayı canlandırmak ve hızlandırmak adına sempatik sinir sistemini etkilemek için ise sağ el ve ayaktaki refleksoloji bölgelerinde uygulama yapmak gerekmektedir. Kişinin rahatsızlığına uygun olarak sağ ya da sol taraftaki bölgeye ağırlık verilmelidir. Örneğin; bireydeki stresi azaltmak için, sol el veya ayakta daha uzun süre çalışılarak parasempatik sinir sistemi uyarılır ve bireyin gevşemesine olanak sağlanır (Çevik, 2013, Stephenson ve ark., 2000).

Tüm bu teorilerin amac1; vücuttaki enerjiyi dengelemektir. Refleksoloji, inaktive olmuş bölgeleri uyararak ya da aşırı aktive olanları yatıştırarak tüm vücut sistemlerini dengelemeye yardım eder (Çevik, 2013).

\section{Refleksoloji Uygulama Teknikleri ve Ayakta Bulunan Refleks Alanları}

Refleksoloji el, ayaklar ve kulaklara uygulanmaktadir. Genel pratikte kulaklar pek kullanılmazken, uygulamanın etkinliği ve rahatlığı açısından genellikle ayaklar tercih edilmektedir. Bir seansı 30 ile 60 dakika arasında süren refleksoloji de parmaklar ya da yardımci araçlar kullanarak ayak tabanındaki refleks noktalarına farklı şekillerde basınç uygulanmaktadır. Bu basıncın oldukça derin olup ac1 verici olmamas1 gerekmektedir. Uygulamada; Ayağin önce pasif hareketlerle gevşemesi ve 1sınması sağlanır, ardından başparmak yürümesürünme tekniği ile ayak tabanı taranır. Çalışma yapılacak noktalara ya da bölgelere temel uygulama tekniklerinden herhangi biri ya da hepsi uygulanabilir. Uygulama yapılacak nokta sayısı çok ise bütün teknikleri uygulamak zaman alacağından bir ya da birkaç teknik ile çalış1labilinir. Refleksoloji başparmak veya başka bir parmağın kenarıyla basınç uygulanarak yapilır (Wang ve ark., 2008).

\section{Refleksolojinin Kullanım Alanları}

Günümüzde hastalıkların büyük bir çoğunluğunun strese bağlı olarak geliştiği bilinmektedir. Korku, stres, üzüntü, endişe ve benzeri olumsuz duygu ve düşünceler homeostasisle birlikte enerji akışında bozulmalara yol açmaktadır. Refleksoloji belirli bir bölgedeki enerji akışını engelleyen herhangi bir bozuklukta, bu bölgelere karşılık gelen sinir sistemi ile birlikte elektromanyetik alanları uyararak sinyallerin akmasını düzene koymakta ve vücutta serbest bir enerji akış1 oluşturmaktadır. Stres varlığında, refleksoloji belirli noktaları uyararak parasempatik sistemi aktive etmekte, stresin azalmasını sağlamaktadır. Stresin azalması veya ortadan kalkması, kan ve lenf dolaşımının artması vücutta yeniden homeostasisin sağlanmasına yardım etmektedir. Refleksolojinin; yüksek seviyede güvenli ve etkili olması, doğal bir yöntem olup ilaç kullanılmaması, non-invaziv olması, öğrenmesi ve uygulamasının kolay olması, gerekli önlemler alındığında herhangi bir zararının olmaması gibi nedenlerle sağlık problemi olan çoğu birey tarafindan tercih edilmektedir (Tucker, 2009). 
Journal of Integrative and Anatolian Medicine

Bütünleyici ve Anadolu Tıbbı Dergisi
Cilt/ Volume: 2 Sayı / Issue: 3 Yil/Year: 2021
Yayınc / Publisher Sağlk Bilimleri Üniversitesi University of Health Sciences

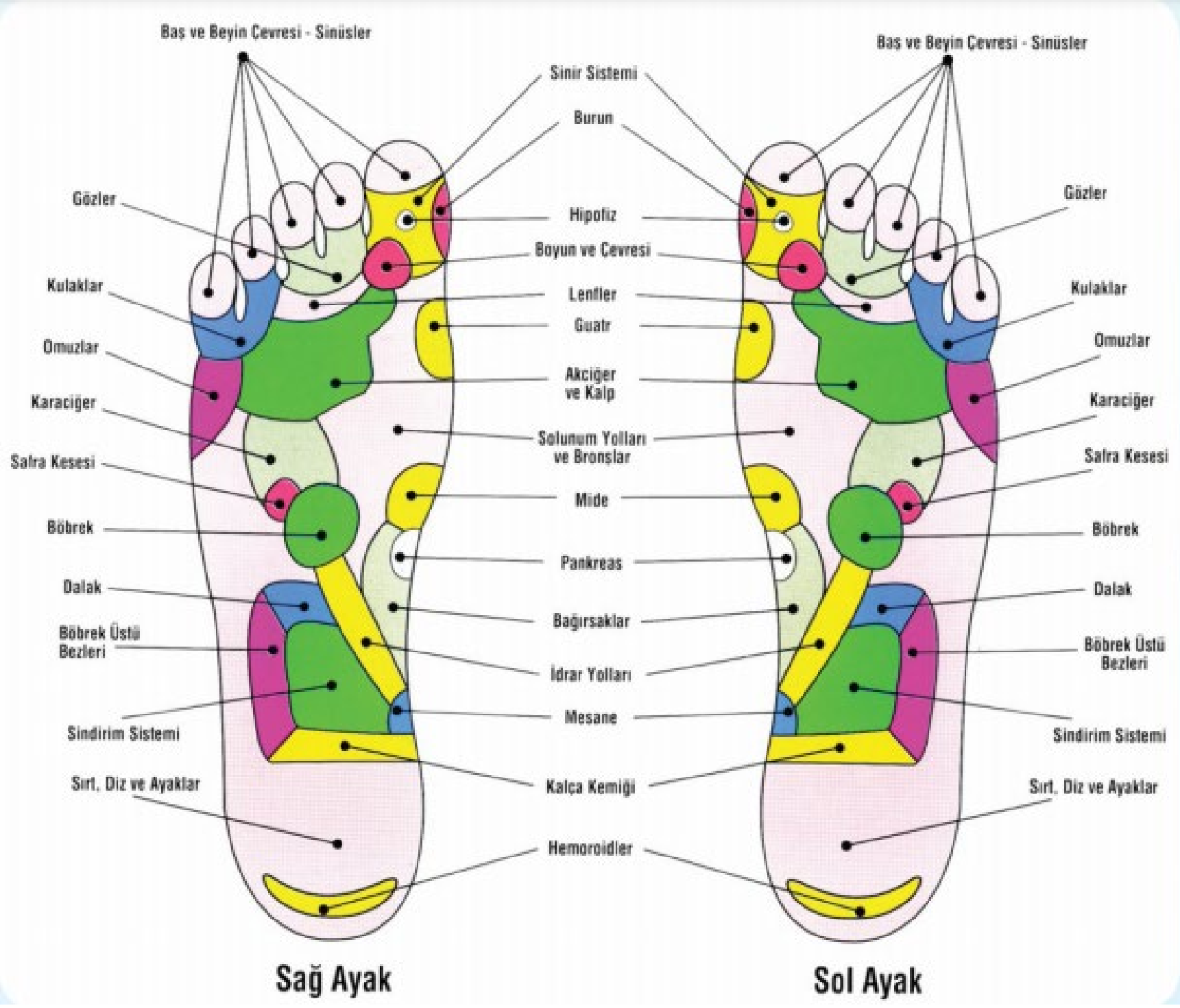

Şekil 3: Ayakta Bulunan Refleksoloji Alanları (Kurt \& Can, 2013).

Refleksoloji birçok rahatsızlığın - Kabızlık, hazımsızlık,

terapisinde/tedavisinde

Bunlardan bazıları;

- Bel ağrisi

- İnme

- Stres

- Multip skleroz

- Diyabetik hastalarda periferal nöropati

- Astım

- Yorgunluk ve gerginliğin azaltılması,

- Sempatik ve parasempatik sistemin işleyişinin düzenlenmesi,

- Eklem ağrıları,

- Depresyon, anksiyete,

- Migren, baş ağrıları,
- Bazı üriner sistem sorunları,

- Menopoz,

- Dismenore,

- Gebelik

- Ödem

- Bulant1-kusmayı azaltmak

- Kanser ağrısı ve kemoterapinin yan etkilerini hafifletmek 
Journal of Integrative and Anatolian Medicine

Bütünleyici ve Anadolu Tıbbı Dergisi
Cilt/ Volume: 2 Sayı / Issue: 3 Yil/Year: 2021
Yayıncı / Publisher Sağlk Bilimleri Üniversitesi University of Health Sciences
$>$ Refleksoloji uygulamasının sakıncalı oluğu durumlar ise;

- Gebeliğin ilk trimestırı

- Akut enfeksiyonlar, ateşli durumlar

- Derin ven trombozu, bacakta varis varlığ

- El, ayak ve kulaklarda lokalize cilt hastalığ
- Ateşli, sistemik veya lokalize olan herhangi bir bulaşıcı hastalık

- Maling melanom

- Açık yaralar

olarak siralanmaktadır (Gunnarsdottir, 2013).

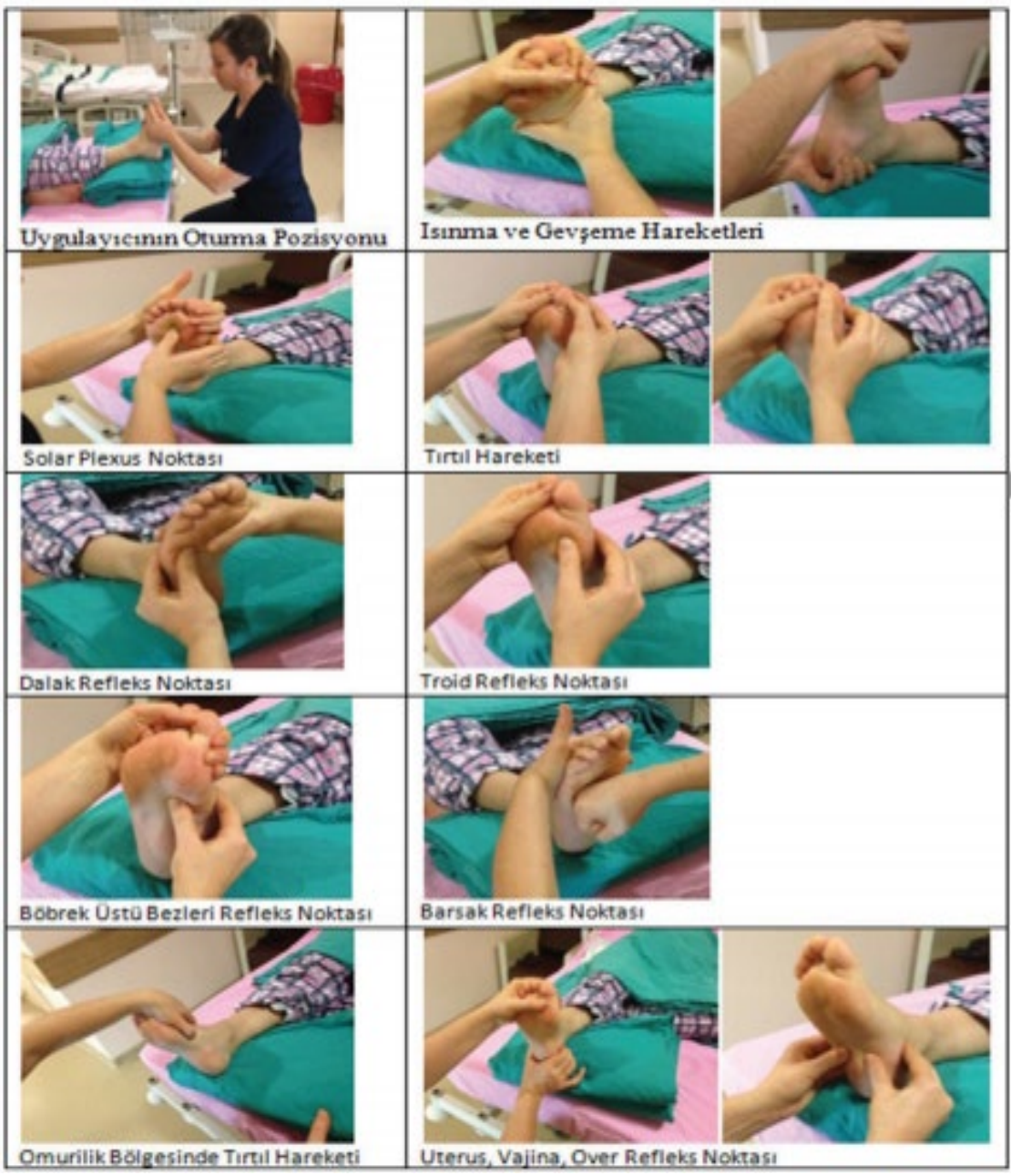

Şekil 3: Ayakta Bulunan Refleks Noktaları ve Uygulama Şekilleri (Y1lar \& Pasinlioğlu, 2017)

\section{Refleksolojinin Faydaları ve Endikasyonları}

Refleksoloji sağlık sorunlarının güvenilir ve etkili tedavisinde, özellikle ilaç kullanmadan kolay uygulama yöntemi nedeniyle tercih edilmektedir. Refleksolojinin birçok faydası bulunmaktadır; stresi azaltmak için ayaklardaki özel bölgelere basınç uygulanırken, hem hedeflenen bölgede hem de tüm vücutta olumlu etkileri görülmektedir. Refleksolojinin ilk uygulamalarında stresin azaltılması ve bireyin rahatlatılmasında etkili iken, tekrarlayan uygulamalarla birlikte genel sağlik üzerinde olumlu etkileri bulunmaktadır (Embong ve ark., 2015).

Ağr1, vücut sisteminde bir stresördür. Vücudun herhangi bir yerinde yaralanma olduğunda vücudun stres mekanizması uyarılmaktadır. Refleksoloji, endorfin ve enkefalin gibi bazı kimyasal mediatörlerin salınımını uyararak bireyin hissettiği ağrı duyusunun azaltılmasını sağlamaktadır (Embong ve ark., 2015). 
Ayaklardaki refleks noktalarına uygulanan basınç sonucunda sinir sistemi aracılığıyla periferik sinir sistemine sinyal gönderdikten sonra, beynin bilgiyi merkezi sinir sisteminde işleme süreci başlamaktadır. Bu süreçte beyin, hücrelere daha fazla besin ve oksijen alınması için iç organlara ve bezlere mesaj göndermektedir. Refleksolojiden maksimum fayda sağlanabilmesi için birkaç seans uygulanması önerilmektedir (Korhan ve ark., 2014).

Refleksoloji genel olarak bireyin fiziksel, emosyonel ve ruhsal açıdan iyilik halinin ve genel sağlık durumunun iyileştirilmesine katk1 sağlamaktadır.

Refleksolojinin faydaları şu şekildedir;

$\checkmark$ Herhangi bir ilaç veya kimyasal kullanılmadan birçok sağlık sorununun iyileşmesinde

$\checkmark$ Ağrının azaltılmasında

$\checkmark$ Özellikle aşırı yorgun el ve ayaklar olmak üzere tüm vücut bölümlerinin genel olarak rahatlatılmasinda

$\checkmark$ Vücutta ağrı giderici kimyasallarının (endorfin ve enkefalin) salınımında

$\checkmark$ Özellikle el ve ayaklardaki herhangi bir bölgedeki hasarda iyileşme sürecini destekleyici olarak (Embong ve ark., 2015)

$\checkmark$ Stresin azaltılması ve gevşeme için

$\checkmark$ Baş ağrısı gerginliğini ve migreni azaltmada

$\checkmark$ Böbrek fonksiyonlarının geliştirilmesinde

$\checkmark$ Geriatrik hastalarda günlük yaşam aktivilerinin artırılmasında

$\checkmark$ Yüksek kan basıncının düşürülmesi ve vücutta kan akışının artırılmasında

$\checkmark$ Serum kolesterol düzeyinin düzenlenmesinde

$\checkmark$ Cerrahi sonrası ağrının azaltılmasında

$\checkmark \quad$ Premenstrüel semptomların azaltılmasında
Ameliyat sonrası iyileşme sürecinin hızlandirılmasında

$\checkmark$ Kanser tedavisi süreci ile ilişkili bulantı, anksiyete ve ağrının azaltılması ve kanser tedavisi sürecindeki algılanan yaşam kalitesinin artırılmasında

$\checkmark$ Sindirim sistemi organlarına olan kan akımının artırılarak konstipasyonun rahatlatılmasinda

$\checkmark$ Tip II diyabet semptomlarının azaltılmasında

$\checkmark \quad$ Bazı artrit çeşitlerinde ağrının azaltılmasında

$\checkmark$ Sporcularda yorgunluk ve kas ağrılarının daha hızlı iyileştirilmesinde, uyku bozukluğunun azaltılması ve uyku kalitesinin geliştirilmesinde

$\checkmark$ Fantom ekstremite hassasiyetinin azaltılmasinda

$\checkmark$ Postravmatik stres bozukluğu, depresyon ve anksiyetenin azaltılmasında

$\checkmark$ Doğum sürecinde, sancisında ve laktasyonda destekleyici olarak kullanılmaktadır (Stone, 2010).

\section{Refleksolojinin Kontrendikasyonları}

Refleksoloji uygulaması birçok sağlık sorununda kullanılabildiği gibi, uygulanmaması gereken bazı durumlar da bulunmaktadır. Refleksoloji uygulaması öncesinde aşağıdaki durumlar iyi değerlendirilmelidir.

Refleksolojinin kontrendike olduğu durumlar şu şekildedir;

$\checkmark$ Herhangi bir enfeksiyon durumunda ve ateş varlığında (bakteriyel veya mantar enfeksiyonu savaşan immün sistemin aşırı uyarılmasına neden olabileceği için)

$\checkmark$ Kırık, gut atağı veya osteomyelit ağrılarının tedavisinde

$\checkmark$ Arteriyel ve venöz yetmezlik sonucu alt ekstremite ülseri olan hastalar

$\checkmark$ Tedavi edilmemiş periferik damar hastalıklarında 
Journal of Integrative and Anatolian Medicine

Bütünleyici ve Anadolu Tıbbı Dergisi
Cilt/ Volume: 2 Sayı / Issue: 3

Yil/Year: 2021
Yayınc1 / Publisher

Sağllk Bilimleri Üniversitesi University of Health Sciences $\checkmark$ Diyabete bağlı periferik nöropatisi olan hastalarda (eğer refleksoloji uygulanıyor ise aterom plaklarının gelişmesi nedeniyle olası doku hasarını önlemek için daha hafif bası ile yapılması önerilmektedir) (Lakasing \& Lawrence, 2010).

Kusma, ishal

Gebelik (özellikle ilk trimester)

El, ayak ve kulaklarda cilt enfeksiyonu bulunan

Tromboz ve tromboflebit

Varisler

$\checkmark \quad$ Malign melanom

Refleksoloji uygulamasına aşırı olumsuz reaksiyon veren hastalar (Gunnarsdottir, 2013).

\section{Refleksoloji ve Ăgrı}

Ağrı kişiye özgü bir duyu olduğu için ağrının algılanma eşiği kişiden kişiye değişiklik gösterir. A ğrı, merkezi sinir sistemine ulaştırılan afferent bir girdi olduğu için, ağrının algılanmasını etkileyen birçok faktörden bir tanesi de refleksoloji uygulamasıdır. Refleksoloji, iyileşmeyi sağlamak için refleks noktalarına özel basınç tekniği uygulanarak gerçekleştirilen enerji dengeleme tedavisidir. Refleksolojinin kap1 kontrol mekanizması ile ağriyı azalttığ düşünülmektedir. Melzack tarafından 1965 y1lında ileri sürülen teoriye göre; kalın dokunma duyusu lifleri, diğer his ileten ince liflerden daha hizlıdır. $\mathrm{Bu}$ nedenle, cilt üzerindeki mekanoreseptörler ve dokunsal duyu lifleri masaj yoluyla uyarılmakta ve substantia gelatinosa hücreleri teşvik edilmekte ve böylece T hücreleri için sinyal inhibisyonuna neden olarak ağrı hissi önlenmektedir (Doğan, 2014).

Dolatian ve arkadaşları doğum süreci yeni başlamış hamilelerde refleksolojinin doğum ağrısına etkisini inceledikleri çalışmada, refleksolojinin algınan ağrının şiddetini azalttığını saptamışlardır (Dolatian ve ark., 2011). Park ve arkadaşlarının yaptıkları çalışmada, meme kanseri nedeniyle ve ameliyat olan hastalara uygulanan refleksolojinin hastaların algıladıkları ağrı düzeylerini olumlu yönde etkilediğini bulmuşlardır (Park ve ark., 2006).

\section{Refleksoloji ve Anksiyete}

Refleksoloji masaji ile enerji teorisi, laktik asit teorisi, endorfin teorisi, sinir reseptörlerini algılama teorisi ve sinir uyarı teorisi aracılığı ile kaslardaki gerginlik giderilir, bunun sonucunda rahatlama ile vücutta enerji akışı sağlanır. Bunun sonucunda ise stres, gerginlik ve anksiyete giderilir (Uysal \& Kutlutükani, 2016).

Koroner anjiyografi olan hastaların yaşadıkları anksiyeteye refleksolojinin etkisinin değerlendirildiği randomize kontrollü bir çalışmada, koroner anjiyografi öncesi uygulanan refleksolojinin anksiyete seviyesini düşürdüğünü ve bu nedenle koroner anjiyografi öncesi hastalara refleksoloji uygulamasının yapılmasını tavsiye ettiği belirtilmektedir (Vardanji, 2013). Hudson ve arkadaşlarının lokal anestezi ile minimal invaziv cerrahi sirasinda hastalara yapılan el refleksolojisinin ağrı, anksiyete ve hasta memnuniyeti üzerine etkisini incelendikleri randomize kontrollü çalışmada, el refleksolojisinin intraoperatif anksiyeteyi önemli derecede azalttığını belirtmişlerdir (Hudson ve ark., 2015). Nesami ve arkadaşlarının koroner arter baypas greft cerrahi olan hastalarda ayak refleksolojisinin anksiyete üzerine etkisini değerlendirdikleri çalışmada, cerrahi sonrası hastaların sol ayaklarına dört gün süreyle yapılan 20 dakikalık masaj sonrası hastaların anksiyete düzeylerinde önemli ölçüde azalma olduğu bildirilmiştir (Bagheri-Nesami ve ark., 2014). Refleksoloji uygulamasında; deneyimlenen ağrı seviyesinin azalması ya da kaybolması, depresyon, anksiyete, stres, yorgunluk ve gerginliğin azaltılması, bedenin hasta bölgesinde karıncalanma hissi, tamamen gevşeme, hoş bir ağırlık ya da hafiflik hissi oluşturması sebebiyle hasta memnuniyeti de artmaktadır (Quattrin ve ark., 2006). 


\section{Refleksoloji ve Stres}

Küreselleşme ile birlikte artan teknolojik hız, rekabete ve aşırı çalışmaya dayanan bir iş ortamını oluşturmaktadır. Yaşanan hızlı değişim ve aşırı çalışma ise bireysel özellikler, çalışma ortamı, çalışma koşulları, örgüt kültürü, örgüt iklimi ve iş ilişkileri ile birlikte iş yaşamındaki stresi artırmaktadır (Örücü ve ark., 2011). Literatüre bakıldığında, stresin yoğun olduğu mesleklerin içinde hemşirelik mesleğinin olduğu ve zaman içerisinde stresin artmasına bağlı olarak bireysel motivasyonda düşme, meslekte kalma isteğini etkileme, iş kazalarında artma ve hizmet kalitesinde azalmalara neden olduğu karşımıza çıkmaktadır (Aydın Sayılan \& Mert Boğa, 2018). Stresin hayatımızdan çıkmasının mümkün olmayacağı ve iş streslerinin tamamen ortadan kaldırmaya çalışmak yerine stresle başa çıkmanın yollarını aramanın daha doğru olduğu bilinmektedir. Sağlığın korunması ve bazı rahatsızlıkların azaltılması amacıyla kullanılan refleksoloji ise stres seviyesini azaltmak için yapılan uygulamalardandır. Refleksoloji aynı zamanda günlük yașamda vücudun herhangi bir stresinden kurtulmasını sağlar ve herhangi bir ilaç ya da kimyasal içermediği için tercih edilir (Embong ve ark., 2015). Doğum sonras1 dönemdeki kadınlara yapılan bir çalışmada, ayak refleksoloji masajının kadınlar için stresi hafifletmede kullanılabilecek bir hemşirelik girişimi olabileceği gösterilmiştir (Choi \& Lee, 2015).

\section{Refleksoloji ve Hemșirelik}

Refleksoloji de dahil olmak üzere birçok TAT uygulaması "Geleneksel ve Tamamlayıcı Tıp Uygulamaları Yönetmeliğgi" yürürlükte değilken ebe ve hemşirelerin refleksoloji tekniğini uygulayabilmeleri için sertifikalarının bulunması yeterliyken, günümüzde ebe/hemşireler, refleksolojiyi 27.10.2014 tarihli, 2915 sayıl1 "Geleneksel ve Tamamlayıc1 T1p Uygulamaları Yönetmeliğinin" Madde 9 Ek 3, kararı doğrultusunda doktor gözetiminde sertifikalı sağlık mensupları yapabilirler (Akköz, 2020). Kullanım alanının genişliği nedeniyle etkili sonuçlar refleksolojinin ayaklara uygulanmasıyla elde edilmektedir (Dolatian ve ark., 2011).

Refleksoloji, özel eğitim gerektiren uygulamalardan biridir. Belli bir eğitim/kurs sürecine dahil olup gerekli sertifikaları aldıktan sonra uygulamaya geçilmelidir. Ülkemizde, ebelik/hemşirelik

uygulamalarında refleksolojiye, yapılan bilimsel çalışmalar dışında, rastlanmamıștır. Kliniklerde refleksoloji uygulamasının rutin bakımlar arsına dahil edilebilmesi için hemşirelerin bu alanda sertifikasyonu sağlanmalıdır. Alanında uzmanlaşmış tamamlayıcı ve alternatif tedavi yöntemleri ile ilgili eğitimli, sertifikalı, kalifiye ebe/hemşireler yetiştirilmelidir (Çevik, 2013).

Ülkemizde 2000-2016 yılları arasında refleksoloji ile ilgili yapılan araştırmaların; \%86.4'ünün akademisyen hemşireler tarafindan yürütüldüğü saptanmıştır. Ayrıca bu araştırmaların \%36.8'nin iç hastalıkları hemşireliği, \%36.8'nin doğum ve kadın sağlı̆̆1 hastalıkları hemşireliği, \%15.8'nin hemşirelik esasları, \%5.3'nün çocuk sağlığı ve hastalıkları hemșireliği, \%5.3'nün ruh sağlı̆̆1 ve hastalıkları hemşireliği anabilim dalındaki akademisyen hemşireler tarafından yürütüldüğü belirlenmiştir (Arslan ve ark., 2017). Sağlık personelleri ile yapılan bir çalışmada da sağlık personelleri tarafından TAT yöntemi kullanım sıklığının \%25 olduğu, en çok kullandıkları TAT yönteminin ise bitkisel yöntem olduğu, \%50'sinin ise refleksoloji yöntemini hiç duymadığ belirlenmiştir (Lafçı \& Kara Kaşıkçı, 2014).

Sağlık alanında teknolojik gelişmelerle birlikte hemşirelerin rol ve sorumluluklarında değişimler meydana gelmiştir. $\mathrm{Bu}$ nedenle hemşirelerden tamamlayıcı tedavilerin kullanımı ile ilgili hemşirelik uygulamalarını geliştirilmeleri, etkili stratejiler belirlemeleri ve bireylerin tamamlayıcı tedavileri etkili ve doğru şekilde kullanmaları konusunda hastaları yönlendirilmeleri beklenmektedir (Gray, 2004). Refleksoloji uygulamasının etkili, basit, invaziv olmayan, güvenilir, alet gerektirmeyen ve maliyeti düşük bir yöntem olması hemşirelik bakımında kullanımını giderek arttırmaktadır (Doğru ve ark., 2017). 
Journal of Integrative and Anatolian Medicine

Bütünleyici ve Anadolu Tıbbı Dergisi
Cilt/ Volume: 2 Sayı / Issue: 3

Yil/Year: 2021
Yayıncı / Publisher

Sağllk Bilimleri Üniversitesi University of Health Sciences

\section{KAYNAKLAR}

Arslan GG, Çınar Yücel Ş, Gökcen M (2017). Türkiye'de 2000-2016 Y1llar1 Arasinda Refleksoloji Uygulamasıyla İlgili Yapılan Çalı̧̧maların Sistematik Analizi. Spatula Ddpeer Reviewed Journal on Complementary Medicine and Drug Discovery, 7: 32-37.

Aydın Sayılan A, \& Mert Boğa S (2018). Hemşirelerin İş Stresi, İş Yükü, İş Kontrolü Ve Sosyal Destek Düzeyi İle Tıbbi Hataya Eğilimleri Arasındaki İlişkinin Belirlenmesi. Hemşirelikte Araştırma Geliştirme Dergisi, 20(1): 11-22.

Akköz Çevik S (2020). Refleksolojinin Doğum Eylemi Üzerindeki Etkisi. Disipliner Yaklaşımla Güncel Sağlık Konuları. Ulutaşdemir N (Edt.). İksad Yayınevi,28-33

Bagheri-Nesami M, Shorofi SA, Zargar N, Sohrabi M, Gholipour-Baradari A, Khalilian A (2014). The Effect of Foot Reflexology Massage on Anxiety in Patients Following Coronary Artery Bypass Graft Surgery: A Randomized Controlled Trial. Complementary Therapies in Clinical Practice, 20(1): 42-47.

Choi SM, \& Lee EJ (2015). Effects of Foot-Reflexology Massage on Fatigue, Stress and Postpartum Depression in Postpartum Women. Korean Society of Nursing Science, 45(4): 587-594

Çevik K (2013). Hemşirelikte Tamamlayıcı ve Alternatif Tedavi: Refleksoloji. Ege Üniversitesi Hemşirelik 2013Fakültesi Dergisi, 29:71-82.

Çakıroğlu G (2013). Refleksoloji. Dördüncü bask1. Kassandara Yayınları, İstanbul:17-18.

Dolatian M, Hasanpour A, Montazeri S, Heshmat R. Alavi H (2011). The Effect of Reflexology on Pain Intensity and Duration of Labor on Primiparas. Iran Red Crescent Med Journal, 13(7): 475-79

Doğru BV, Yıldırım Y, Aykar FŞ (2017). Kardiyovasküler Hastalıklar ve Refleksoloji. Journal of Cardiovascular Nursing, 8(17): 77-85.

Doğan HD (2014). Ellerin İyileştirme Sanatı: Refleksoloji. European Journal of Basic Medical Science, 4(4):89-94

Dinler Y (2015). Refleksoloji, Cinius Yayınları:10-40.

Embong NH. Soh YC, Ming LC, Wong TW (2015). Revisiting Reflexology: Concept, Evidence,
Current Practice, and Practitioner Training. Journal of Traditional and Complementary Medicine, 5(4): 197-206.

Gözüyeşil E (2015). Refleksoloji. Başer M, \& Taşçı S, (Ed.). Kanıta Dayalı Rehberleriyle Tamamlayıcı ve Destekleyici Uygulamalar. Akademisyen Tip Kitabevi, Ankara: 101-112.

Gunnarsdottir TJ (2013). Reflexology. In R. Lindquist, M. Snyder, M. Fran Tracy (Eds.). Complementary and Alternative Therapies in Nursing: Seventh Edition. Springer Publishing Company:103-121.

Gray DP (2004). Complementary and Alternative Therapies. İçinde Lewis, SM., Heitkemper, L. ve Dirksen, SR. (Eds), Medical Surgical Nursing. St. Louis: Mosby Inc.; 94-109.

Hudson FB, Davidson J, Whiteley MS (2015). The Impact of Hand Refleology on Pain, Anxiety and Satisfaction During Minimally Invasive Surgery Under Local Anaesthetic: A Randomised Controlled Trial. International Journal of Nursing Studies, 52(1): 1789-1797.

Horosanlı E, Usta B, Yeşilçay A (2008). Medikal akupunktur. Yeni Tip Dergisi, 25: 70-75.

Kurt S, \& Can G (2013). Refleksoloji Ve Kullanım Alanları. Sağlıkla Hemşirelik Dergisi, 3: 54-55

Korhan EA, Khorshid L, Uyar M (2014). Reflexology: Its Effects on Physiological Anxiety Signs and Sedation Needs. Holistic Nursing Practice, 28(1): 6-23.

Lakasing E, \& Lawrence D (2010). When to Use Reflexology. Primary Health Care, 20(1): 16-19.

Laf̧̧ı D, \& Kara Kaşıkçı M (2014). Yataklı Sağlık Kuruluşunda Görev Yapan Sağlık Personelinin Tamamlayıcı ve Alternatif Tedavi Yöntemlerini Bilme ve Kullanma Durumları. Gümüşhane Üniversitesi Sağllk Bilimleri Dergisi, 3(4): 1-18.

Metin ZG, \& Ozdemir L (2016). The Effects of Aromatherapy Massage and Reflexology on Pain and Fatigue in Patients with Rheumatoid Arthritis: A Randomized Controlled Trial. Pain Manag Nurs, 17(2):140-149.

Örücü E, Kılıç R, Ergül A (2011). Çalışma Yaşamında Stresin Bireysel Performans Üzerindeki Etkileri: Eğitim ve Sağlık Çalışanlarına Yönelik Bir 
Journal of Integrative and Anatolian Medicine

Bütünleyici ve Anadolu Tibbı Dergisi
Cilt/ Volume: 2 Sayı / Issue: 3 Yil/Year: 2021
Yayınc / Publisher Sağlk Bilimleri Üniversitesi University of Health Sciences
Araştırma. Uluslararası Hakemli Sosyal Bilimler Dergisi, 26: 1-2.

Park JW, Yoo HR, Lee HS (2006). Effects of Foot Reflex Zone Massage on Patients Pain and Sleep Satisfaction Following Mastectomy. J Korean Acad Soc Home Care Nurse; 13(2): 54-60.

Quattrın R, Zanını A, Buchını S, Turello D, Annunziata MA, Vidotti C, Colombatti A, Brusaferro S (2006). Use of reflexology foot massage to reduce anxiety in hospitalized cancer patients in chemotherapy treatment: methodology and outcomes. Journal of Nursing Management, 14: 96-105.

Stone V (2010). The World's Best Massage Techniques The Complete Illustrated Guide: Innovative Bodywork Practices From Around The Globe For Pleasure, Relaxation, and Pain Relief. (Firsth Edition). USA: Quarto Publishing Group:103121.

Stephenson NL, Weinrich SP, Tavakoli AS (2000). The Effects of Foot Reflexology on Anxiety and Pain in Patients With Breast and Lung Cancer. Oncol Nurs Forum,27: 67-72.

Tucker T (2009). Reflexology. London; Published by EMS.

Uysal N, \& Kutlutürkani S (2016). Kanserli Bireylerde Semptom Kontrolünde Refleksoloji Uygulaması. Bakırköy Tıp Dergisi,12(3):103-109

Wang MY, Tsai PS, Lee PH, Chang WY, Yang CM. (2008). The efficacy of reflexology - systematic review. J Adv Nursing, 62(5): 512-520.

Vardanji MM (2013). A Randomized-Controlled Trial Examining The Effects of Reflexology on Anxiety of Patients Undergoing Coronary Angiography. Nursing and Midwifery Studies, 2(1): 3-9

Yıldız S, \& Yaşa Öztürk G (2014). Refleksoloji: Temel ve Klinik Bilgiler. İntegratif Tıp Dergisi, 2(1): 26-42.

Yılar EZ, \& Pasinlioğlu T (2017). Doğum Ağrısında Alternatif Bir Yöntem: Ayak Refleksolojisi. Hacettepe Üniversitesi Hemşirelik Fakültesi Dergisi, 4(1): 53-61 